\title{
Lessons for Children's Rights from Disability Rights?
}

\section{Introduction: is there anything new for children in the CRPD?}

\subsection{A pessimistic reading}

This chapter asks whether International Child Law (ICL) can learn any lessons from recent developments in International Disability Law (IDL). At first glance, this might perhaps seem to be an odd question. After all, the main instrument of ICL, the United Nations Convention on the Rights of the Child (CRC), is now more than 25 years old whereas the IDL equivalent, the United Nations Convention on the Rights of Persons with Disabilities (CRPD) is a much younger document. It was adopted by the United Nations General Assembly, on 13 December 2006, opened for signing in March 2007, and came into force, following its $20^{\text {th }}$ ratification, on 3 May 2008. ${ }^{1}$ In a sense, the CRC is the adult and the CRPD is the child, and it might appear more likely that the CRPD could take lessons from the CRC than vice-versa. One reason for holding this view is that ICL has in the $21^{\text {st }}$ century moved decisively from questions relating to the articulation of rights in abstract textual form to their realisation in practice. A decade or so ago, Kofi Annan called, in the context of child soldiers, for an 'era of application', ${ }^{2}$ and this is an apt description of the current state of international children's rights more generally. Children's rights were closely interwoven into the pursuit of the Millennium Development Goals (MDGs) set in 2000, and we have in recent times seen time-bound campaigns aimed at the abolition of the worst forms of child labour by 2016; education for all by 2015; the eradication of FGM 'within a generation'; the eradication of child soldiers; and a whole host of sub-goals. All of these developments, grounded in ICL, were well underway whilst those interested in disability rights were still trying to agree the substantive content and scope of IDL and the text of the CRPD. As a consequence, for example, the MDGs do not make any mention of disability.

Moreover, when the finished text of the CRPD did emerge, it was presented, in UN discourse at least, as not particularly innovative. The CRPD was conceptualised as an implementation

\footnotetext{
${ }^{1}$ As of 26 May 2016, the Convention had been signed by 160 and ratified by 164 state parties. Its Optional Protocol had at tracted 92 signat ures and 89 ratifications by the same date $h$ ttp://www.un.org/disabilities/.

${ }_{2}^{2}$ United Nations, Children and Armed Conflict Report of the Secretary General, A/58/546-S/2003/1 053, para. 104.
} 
convention', ${ }^{3}$ designed not to create new rights but, rather, to implement existing human rights law ${ }^{4}$ in the field of disability: all prior-existing international human rights treaties (bar the CRC: see below) having been silent on the particular diffic ulties faced by people with disabilities. According to the United Nations Disabilities Handbook for Parliamentarians, 'The Convention is a complement to existing international human rights treaties. It does not recognize any new human rights of persons with disabilities, but rather clarifies the obligations and legal duties of States to respect and ensure the equal enjoyment of all human rights by all persons with disabilities'.5 This is reflected in Article 1, the first of two interpretative articles, which states that the purpose of the CRPD is to:

Promote, protect and ensure the full and equal enjoyment of all human rights and fundamental freedoms by all persons with disability, and to promote respect for their dignity.

Article 1 is buttressed by the statement of the general obligations of state parties in Art 4, which is to bring about 'the full realisation of all human rights and fundamental freedoms for all persons with disabilities'. The CRPD was, in essence, presented at the time of its emergence as a corrective rather than an innovative measure, as far as the broader human rights landscape was concerned.

A quick perusal of the text of the CRPD appears to confirm a conservative view of its wider import. It contains what looks like a fairly standard list of political/civil and social, economic and cultural rights. Political and civil rights in the CRPD include:

Art 10: Right to Life

Art 13: Access to Justice

Art 14: Liberty and Security of the Person

Art 15: Freedom from torture or cruel, inhuman or degrading treatment or punishment

\footnotetext{
${ }^{3}$ UN Press Releases, 'Chairman says draft convention sets out 'detailed code of implementation and spells out how individual rights should be put into practice', 15 August 2005, SOC/4680, available at: http://www.un.org/News/Press/docs/2005/soc4680.doc.htm last accessed 25 May 2015.

${ }^{4}$ I.e. the Universal Declaration of Human Rights 1948, the International Covenant on Civil and Political Rights 1966 (ICCPR) and the International Covenant on Economic, Social and Cult ural Rights 1966 (ICESCR). Both the CRC and the CRPD are included in the $n$ ine core UN treaties: See The Core International Human Rights Instruments and their monitoring bodies, available at http://www.ohchr.org/EN/ProfessionalInterest/Pages/CoreInstruments.aspx last accessed 25 May 2015.

${ }^{5}$ UN Secretariat for the Convention on the Rights of Persons with Disabilities, United Nations Department of Economic and Social Affairs (un-DEsa), Secretariat for the Convention on the Rights of Persons with Disabilities, Office of the United Nations High Commissioner for Human Rights (oHcHr), Inter-Parliamentary Union No 14-2007 (2007) United Nations Handbook for Parliamentarians, From Exclusion to Equality, Realizing the Rights of Persons with Disabilities (United Nations), 5.
} 
Art 16: Freedom from exploitation, violence and abuse

Art 18: Liberty and Nationality

Art 21: Freedom of Expression

Art 22: Privacy

Art 23: Home and Family

Art 29: Participation in Political and Public Life.

Social, economic and cultural rights in the CRPD include:

Art 24: Education

Art 25: Health

Art 27: Work and Employment

Art 28: Standard of Living and Social Protection

Art 30: Participation in Cultural Life, Recreation and Sport

Moreover, the CRPD apparently stays on traditional ground as far as the realisation of human rights is concerned. Article 4.2 uses the familiar form of words which provides that although political and civil rights are 'immediately applicable according to international law', a state party must work towards the full realisation of economic, social and cultural rights 'to the maximum of its available resources'. There is little scope here, or so it would seem, for the CRPD to provide some 'added value' to the CRC.

The repudiation of any innovative aspect to the CRPD at the general level is repeated in the particular context of the rights of children. Although containing a number of specific provisions relating to children with disabilities, the CRPD has been presented as being concerned primarily with the rights of adults; and it has not attracted much attention from those in the academic community interested in the rights of children. ${ }^{6}$ This may be because of an understanding that the approach taken in the CRPD is to channel the rights of children with disabilities back into the rights regime that applies to other children under the CRC. Paragraph (r) of the Preamble to the CRPD recognises that children with disabilities 'should have full enjoyment of all human rights and fundamental freedoms on an equal basis with other children,

\footnotetext{
${ }^{6}$ For a rare example, see Georgette Mulheir 'Deinstitutionalisation - A Human Rights Priority for Children with Disabilities' (2012) 9 The Equal Rights Review 117.
} 
and recalls 'obligations to that end undertaken by State Parties to the Convention on the Rights of the Child'. Article 7 of the CRPD, which is headed 'Children with disabilities', is as follows:

1. States Parties shall take all necessary measures to ensure the full enjoyment by children with disabilities of all human rights and fundamental freedoms on an equal basis with other children.

2. In all actions concerning children with disabilities, the best interests of the child shall be a primary consideration.

3. States Parties shall ensure that children with disabilities have the right to express their views freely on all matters affecting them, their views being given due weight in accordance with their age and maturity, on an equal basis with other children, and to be provided with disability and age-appropriate assistance to realize that right.

Articles 7.2 and 7.3 are of course familiar to international child lawyers as reworked versions of Arts 3.1 and 12 of the CRC. Read together with the reference to 'other children' in Art 7.1 and in the Preamble, it seems clear that the intention behind the CRPD in relation to children is as it is more generally, to offer the same level of human rights protection to the target group as is enjoyed by other citizens, to remove discrimination and equalise the position of children with disabilities, but not to enhance the rights protection of children generally.

As preamble para (r) makes clear, the CRPD was drafted with the existing provision in respect of children with disabilities in the CRC in mind. Article $2 \mathrm{CRC}$ prohibits discrimination against a child for a number of reasons, including disability. Article 23 provides a rare pre-2006 example of a stand-alone provision regarding disability rights and commits state parties to ensure the provision of 'special care' for children with disabilities in a wide variety of fields on account of their 'special needs':

1. States Parties recognize that a mentally or physically disabled child should enjoy a full and decent life, in conditions which ensure dignity, promote self-reliance and facilitate the child's active participation in the community.

2. States Parties recognize the right of the disabled child to special care and shall encourage and ensure the extension, subject to available resources, to the eligible child 
and those responsible for his or her care, of assistance for which application is made and which is appropriate to the child's condition and to the circumstances of the parents or others caring for the child.

3. Recognizing the special needs of a disabled child, assistance extended in accordance with paragraph 2 of the present article shall be provided free of charge, whenever possible, taking into account the financial resources of the parents or others caring for the child, and shall be designed to ensure that the disabled child has effective access to and receives education, training, health care services, rehabilitation services, preparation for employment and recreation opportunities in a manner conducive to the child's achieving the fullest possible social integration and individual development, including his or her cultural and spiritual development.

4. States Parties shall promote, in the spirit of international cooperation, the exchange of appropriate information in the field of preventive health care and of medical, psychological and functional treatment of disabled children, including dissemination of and access to information concerning methods of rehabilitation, education and vocational services, with the aim of enabling States Parties to improve their capabilities and skills and to widen their experience in these areas. In this regard, particular account shall be taken of the needs of developing countries.

Given the prior existence of Art $23 \mathrm{CRC}$, many delegates were of the opinion during the drafting of the CRPD that there should be no reference to children in the new convention, ${ }^{7}$ and specific mention was ultimately made of children with disabilities in the CRPD only on the basis that to do so would not conflict with Art 23 CRC. ${ }^{8}$ All of this seems to indicate that we should not expect too much in terms of innovation for children's rights from this quarter, particularly as Art 23.2 identifies the right of the disabled child to special care as a social right, and the extent of its realisation therefore subject to the availability of resources.

\subsection{An optimistic reading}

The above sketch of the CRPD bears scant resemblance to the way in which the convention has been analysed in some of the academic literature. For Amita Dhanda, for example, the

\footnotetext{
${ }^{7}$ Marianne Schulz, Understanding The UN Convention On The Rights Of Persons With Disabilities ( $3^{\text {rd }}$ ed, Handicap International, 2009) 69.

${ }^{8}$ Schulz (n 7), ibid.
} 
CRPD can be seen in terms of nothing less than 'constructing a new human rights lexicon'. ${ }^{9}$ For Frédéric Mégret, in a similar vein:

...the Disabilities Convention has an approach to the issue of rights which rather cavalierly (but very beneficially) ignores or reinvents some perennial dichotomies of the 'mainstream' of human rights. This is, I contend, because disability forces human rights lawyers to reexamine some core assumptions about what the needs of human beings are, and how these relate to society and the state. There is a lesson in this for human rights itself, of course, which can gain tremendously from the resulting, more holistic, concept of rights that emerges. ${ }^{10}$

Mégret argues that disability forces this re-examination because of the radical developments in its underpinning model which have occurred over the past few decades. It is not contentious to state that the field of disability has been transformed over that period at the level of its conceptual base. From a starting position which viewed disability in welfarist, charitable and medicalised terms, with state policy the collective expression of pity for the inherent disability of the sufferer, disability is now seen instead in terms of human rights and equality 'premised on a holistic "social model"11 of disability, which understands, as it is put at para (e) of the Preamble to the CRPD, that 'disability results from the interaction between persons with impairments and attitudinal and environmental barriers that hinder their full and effective participation in society on an equal basis with others'.

The CRPD itself is the best and most concrete expression of this change of thinking. The point is put more concisely by Thomas Hammarberg, at the time Council of Europe Commissioner for Human Rights, writing the Key Note introduction to a Special Edition of the European Human Rights Law Review on the CRPD published in 2011, 'we have come to see the source of the problem: the society's attitude towards persons with disabilities'. ${ }^{12}$ This may be putting the point too strongly. As Judith Butler for one has pointed out, ${ }^{13}$ as embodied beings there is a material reality to our existence which is beyond social or psychic construction, just as the

\footnotetext{
${ }^{9}$ A Dhanda, 'Constructing a new human rights lexicon: Convention on the Rights of Persons with Disabilities' (2008) 8 International Journal of Human Rights 43.

${ }^{10}$ Frédéric Mégret,'The Disabilities Convention: Towards a Holistic Concept of Rights' (2008) 12(2) The International Journal of Human Rights, 261,262.

${ }^{11}$ Grainne de Birca ‘TheEuropean Union in the negotiation of the UN Disability Convention' (2010) European Law Review, $174,175$.

12 Thomas Hammarberg, 'Disability rights: from charity to equality' (2011) 6 European Human Rights Law Review, 638-641 at 639.

13 Judith Butler, Bodies that Matter: on the discursive limits of 'sex' (Routledge, 1993).
} 
child exists beyond any social or cultural construction of childhood. Social attitudes are not the sole cause of individual disability. But social attitudes, norms and practices are certainly major and variable vectors of disability-related discrimination. They may not constitute the entirety of 'the problem', of what is problematic about, disability; but they do constitute a very significant part of it, and it is the part which can, in theory at least, be most readily attended to and even prevented from arising by state action underpinned by a discourse of rights and equality.

How this links to the way in which rights are understood is that a 'holistic' approach entails the undermining of traditional divisions within orthodox human rights discourse. For example, the right to vote is for a person with a perambulatory disability of little use unless the polling station is accessible to persons with his or her particular disability. Hence, the exercise of a political right - the right to vote - depends intimately for its realisation in practice on the reality of a social right - the right of access. To generalise the point, it is that the realisation of political and civil rights is dependent on the prior or simultaneous realisation of social, economic and cultural rights. Work in this area chimes with the development of theories of vulnerability by writers such as Fineman, ${ }^{14}$ who argues that it is the vulnerability which constitutes us all in our humanity which should underpin human rights, because to realise that we are all vulnerable to illness, disability or other misfortune, is, again, to recognise the social underpinning of the civil and political rights of the individual.

It is on this basis that Mégret proceeds to argue that the CRPD reconfigures four major distinctions in international law, between types of rights (political and social, negative and positive, and so on); between actors (state as principal actor and other actors); in terms of the 'intensity' of rights (immediate realisation and progressive realisation); and modes of implementation (law and policy). Indeed, returning to Art 7.3 of the CRPD, it can be seen that the modification of that article by comparison to Art $12 \mathrm{CRC}$, which is achieved by adding its final stanza, requires that a child with disabilities is afforded not merely the right to free expression of his or her views and for those views to be given due weight, but also the right 'to be provided with disability and age-appropriate assistance to realize that right'. The assistance, as well as the substantive right to be heard, must be 'ensured' by the state (the whole of Art 7.3 being governed by the state's obligation to 'ensure' that its aims be achieved). The right to

\footnotetext{
14 Martha A. Fineman, 'The Vulnerable Subject: Anchoring Equality in the Human Condition' (2008) 20 Yale Journal of Law and Feminism, 1 .
} 
assistance - a social right - has been tagged on to the right to be heard - a civil right - and, seemingly, made subject to the same obligation to immediate realisation. This indivisibility of rights gives expression to a prior understanding of the indivisibility of needs and, ultimately, the indivisibility of the self.

In addition, Art 4.2 - although repeating the orthodox distinction between, on the one hand, civil and political rights, which are 'immediately applicable according to international law' and, on the other, economic, social and cultural rights, which are subject to progressive realisation as resources permit - is worded differently from other versions of the distinction, such as that found in Art 4 CRC. The distinction in the CRPD must be read according to Art 4.2 'without prejudice to those obligations contained in the present Convention that are immediately applicable according to international law'. It might be that 'those obligations' refers only to civil and political rights, but if that was the case, civil and political rights could have been explicitly mentioned in Art 4.2 and contrasted with economic, social and cultural rights - which Art 4.2 does specifically refer to - and so arguably the best interpretation of its final stanza is that it countenances that some CRPD rights conventionally seen as economic, social or cultural could nonetheless be subject to immediate realisation; which lends support, for example, to the above reading of the significance of Art 7.3. At the very least, the final stanza of Art 4.2 introduces some ambiguity into interpretations of its potential scope and effect.

Other elements of the CRPD are equally intriguing and thought-provoking for international children's rights strategists. For instance, the CRPD exhibits an attitude towards a role for a test of capacity which lies somewhere between sceptical and downright hostile. It has been argued by some, including the UN High Commissioner for Human Rights, ${ }^{15}$ that capacity as a mechanism for the removal of rights has been jettisoned altogether by the CRPD, which if correct means that only ICL retains faith in the concept of capacity as an acceptable mechanis m to regulate the exercise of rights by the right-holder, and suggests that it is at least worthwhile to investigate whether the same arguments that have been so influential in IDL should also be considered in ICL. It is important to understand that there is controversy and, as of yet, a lack of clarity about exactly what the CRPD represents in terms of innovation. Some academic voices are circumspect about the extent to which the CRPD can be seen as a radical departure

\footnotetext{
${ }^{15}$ UN High Commissioner for Human Rights, Annual Report A/HRC/10/48, 26 January 2009, paras 45, 47.
} 
from existing norms of both international human rights law and practice and disability law and practice, ${ }^{16}$ but there is a broad consensus that, even if the CRPD does not as it stands exemplify the claims made for it by Mégret, then it certainly has the potential to do so.

There are further factors which suggest that the possible impact of the CRPD on ICL may be worth pondering. The CRPD follows earlier conventions such as the CRC by establishing a committee of experts, the Committee on the Rights of Persons with Disabilities (in Art 34), to which state parties must report, initially within two years of the convention coming into force in the jurisdiction in question, and thereafter every four years (Art 35) on progress in meeting the requirements of the convention. And as with the CRC, there is an Optional Protocol (OP) to the CRPD,${ }^{17}$ under the terms of which the Committee on the CRPD can hear complaints made by or on behalf of individuals. But unlike the CRC, the OP to the CRPD was opened for signature alongside the main convention in March 2007, whereas the OP to the CRC was only added recently, more than two decades after the parent convention. ${ }^{18}$ That the CRC existed for many years without such an OP perhaps demonstrates that it is in some sense 'old-fashioned', the product of the thinking of an earlier, more cautious generation of human rights advocates. Certainly, in the years after 1989, public international law has at a general level begun to encompass the claims of individuals, rather than regulating only the relationship between states. Perhaps, then, the CRPD does contain what Dhanda has termed 'the wisdom of a straggler'. ${ }^{19}$

The final reason for optimism is that the arguments against specific mention of children in the CRPD, although forcefully made, were, as seen, ultimately unsuccessful. The day was won by the opposing view: that it was necessary to include specific provision for children with disabilities in the new convention because such children must often deal with issues that are not faced by other children or by adults with disabilities: issues such as the failure to register the birth of a disabled child or the particular discrimination and threats including violence that are faced by children with disabilities. So, although allegedly not conflicting with Art $23 \mathrm{CRC}$, the CRPD is intended to extend and increase the protection given to the rights of children with disabilities, over and above that provided by the $\mathrm{CRC}$, to the extent necessary to equalise the

\footnotetext{
${ }^{16}$ P. Fennell and U. Khaliq 'Conflicting or complementary obligations? The UN Disability Rights Convention, The European Convention on Human Rights and English Law' (2011) 6 European Human Rights Law Review, 662, 669; P. Bartlett, 'The United Nations Convention on the Rights of Persons with Disabilities and Mental Health Law' (2012) 75(5) Modern Law Review 752.

${ }^{17}$ UNGA, Optional Protocol to the Convention on the Rights of Persons with Disabilities, A/RES/61/106, 24 January 2007.

${ }_{18}^{18}$ UNGA, Optional Protocol to the Convention on the Rights of the Child on a communications procedure, A/RES/66/138, 27 January 2012.

${ }^{19}$ Dhanda (n 9), 48.
} 
position of all children. In fact, as will be discussed shortly, not only does the CRPD make specific provision for children with disabilities in Art 7, it also weaves the rights of children with disabilities right across the text of the convention.

The remainder of this chapter will pursue this optimistic reading of the potential for the improvement of the rights of children offered by the CRPD. I will first discuss the new rights for children with disabilities to be found in the CRPD, then consider the extent to which the convention provides new rights for all, before moving on to discuss the ways in which it also extends and reconfigures existing rights. Finally, I shall give some space to the implications for the continued desirability of a role of 'capacity' and 'best interests' as mechanisms for making decisions in relation to children, in the light of the significant departures in this respect contained in the CRPD.

\section{New rights for children with disabilities}

The CRPD aims to implement a sophisticated strategy in pursuit of the goal of equal rights for children with disabilities. It adopts a different approach from that taken in the CRC. In the $\mathrm{CRC}$, as seen above, one article is allocated specifically to the rights of children with disabilities, leaving those interpreting the convention to read those rights into its other articles for themselves, albeit with rather belated assistance from the Committee on the Rights of the Child. ${ }^{20}$ The CRPD, by contrast, both highlights the specific situation of children with disabilities (in Art 7, discussed above) and weaves the particular rights and entitlements of children with disabilities by way of numerous further references into the final text of the CRPD more generally. This strategy is perhaps something that any revised version of the CRC could usefully adopt. $^{21}$ In terms of the second strand of this strategy, which can be called 'mainstreaming':

- One of the general principles of the CRPD, Art 3(h), requires 'Respect for the evolving capacities of children with disabilities and respect for the right of children with disabilities to preserve their identities';

\footnotetext{
20 The CRC published a General Comment on the rights of children with disabilities in early 2007 (prompted, it seems, by activity around the CRPD), advising state parties that the rights of children with disabilities must be implemented 'in a comprehensive manner which covers all provisions of the [CRC]'. CRC Committee 'General Comment number 9: The rights of children with disabilities' UN Doc CRC/C/CG9, $27^{\text {th }}$ February 2007, para. 6 .

${ }^{21}$ The CRC Committee implicitly acknowledges this lacuna in the protection offered to children with disabilities by the CRC by elaborating a mainstreaming programme in its General Comment number 9.
} 
- There is an obligation placed on state parties to consult persons with disabilities in developing national law and policy in conformity with the CRPD, which extends to children with disabilities, albeit through their representative organizations (Art 4.3);

- There is an obligation placed on state parties to foster at all levels of the education system, including in all children from an early age, an attitude of respect for the rights of persons with disabilities (Art 8.2(b));

- There is an obligation placed on state parties to put in place effective legislation and policies, including child-focused legislation and policies, to ensure that instances of exploitation, violence and abuse against persons with disabilities are identified, investigated and, where appropriate, prosecuted (Art 16.5);

- There is an obligation imposed on state parties to take effective and appropriate steps to ensure, inter alia, that all persons with disabilities, including children, retain their fertility on an equal basis with others (Art 23.1(c));

- There is an obligation placed on state parties to ensure that children with disabilities have equal rights with respect to family life. With a view to realizing these rights, and to prevent concealment, abandonment, neglect and segregation of children with disabilities, state parties shall undertake to provide early and comprehensive information, services and support to children with disabilities and their families (Art 23.3);

- Children with disabilities have a right not to be separated from their parents against their parents' will except by legal process which acts only in the best interests of the child, and 'In no case shall a child be separated from parents on the basis of a disability of either the child or one or both of the parents' (Art. 23.4);

- There is an obligation placed on state parties, where the immediate family is unable to care for a child with disabilities, to undertake every effort to provide alternative care within the wider family, and failing that, within the community in a family setting (Art. 23.5);

- Children with disabilities have a right not to be excluded from the general education system and from free primary and secondary education on the basis of disability (Art 24.2(a));

- There is an obligation placed on state parties to provide those health services needed by persons with disabilities specifically because of their disabilities, including early 
identification and intervention as appropriate, and services designed to minimize and prevent further disabilities, including among children and older persons (Art 25(b));

- There is an obligation placed on state parties to ensure that children with disabilities have equal access to play, recreation and sporting facilities (Art 30.5(d)).

There is also specific mention of the rights of blind, deaf and deafblind children, ${ }^{22}$ and of the rights of girl-children with disabilities. ${ }^{23}$

There are two issues here. The first is the technical question, of whether the concept of mainstreaming is better supported, as it is in ICL, by one dedicated article in the text of the convention supported by an explanatory General Comment, or by specific and systematic sequence of references on the face of the convention itself. It seems clear that the latter course, the one adopted with the CRPD, is preferable. The second issue concerns substance. The language relating to children in the main body of the CRPD, as with that used in Art 7, the dedicated article, is sometimes borrowed wholesale from the CRC. For example, Art 23.4 CRPD contains the right of the child 'not be separated from his or her parents against their will, except when competent authorities subject to judicial review determine, in accordance with applicable law and procedures, that such separation is necessary for the best interests of the child' found in Art 9 CRC. But there are clearly new rights for children with disabilities included in the above list.

Some of these are addressed at wrongs that have historically been suffered by children and families living with disability. One important example is the obligation placed on states to ensure that 'all persons with disabilities, including children, retain their fertility on an equal basis with others', found in Art 23.1(c), which prohibits eugenic or quasi-eugenic practices incompatible with the right to procreate of persons with disabilities. Further examples include Art 23.4's stipulation, that 'In no case shall a child be separated from parents on the basis of a disability of either the child or one or both of the parents', and Art 23.5's requirement that states 'undertake every effort to provide alternative care within the wider family, and failing that, within the community in a family setting' when it is necessary in the best interests of a child to remove him or her from the parental home.

\footnotetext{
${ }^{22}$ Art 24.3(c).

${ }^{23}$ Preamble para (q); Art 6.1 and Art 28.2(b).
} 
It might be argued that Art 23.4, which seems to place an absolute embargo on factoring disability into best interests-based decision-making, actually goes considerably further than was needed to address the discriminatory practice, of removing children with disabilities from their families and raising them instead in state institutions. There will, inevitably, be situations in which a contextualised, reasonable and sometimes morally imperative, judgment will be made that, because of the presence of some physical or mental impairment of either parent and/or child, it is in the best interests of the child to be separated from his or her family, whether permanently or temporarily (and Art 23.4 contains no temporal reference). Such situations are by definition extreme in their facts and should be rare, but they will and do arise. Here the CRPD seems to exhibit dogma which does not countenance (what will sometimes be) the realities of the situation. But concerns that this provision has been drafted too widely or too clumsily in no way detract from its importance or, indeed, necessity, as a mechanism to condemn and ultimately, facilitate the eradication of, state policies and practices which prefer or allow the routine institutionalisation of children with disabilities. Shifting care wholly out of institutions and into the family or, failing that, the wider community, as required by Arts. 23.4 and 23.5, naturally entails the reallocation, and most probably, the provision of further, resources, and provides leverage for NGOs and the international community at large to bring pressure to bear on recalcitrant governments. These provisions, then, do enhance the protection of children with disabilities over and above that offered by Arts 2 and 23 CRC. They are also a long way, in philosophical terms, from accepting the propriety of the 'placement in suitable institutions for the care of children' of children removed from their families, licensed by Art 20.3 CRC.

Some rights found in the CRC, namely the right, in Art 5, to have evolving capacities recognised, or that in Art 8, to have one's identity preserved, have been elevated to the status of a general principle in the CRPD. Others - such as the obligation placed by Art 16.5 CRPD on states in respect of exploitation, violence and abuse suffered by children with disabilities which is reminiscent of Art 19 CRC, provide added value because, unlike that article, Art 16.5 CRPD contains specific reference to the obligation to prosecute where appropriate. Other rights still are genuinely novel. The right of disabled children to be consulted by states when bringing national law into conformity with the CRPD, found in Art 4.3 CRPD, goes beyond anything guaranteed by the CRC. The obligation on the state to ensure that disabled children have equal rights with respect to family life in Art 23.3 CRPD is couched in much more positive terms than the negative formulation of Art $16 \mathrm{CRC}$, which merely forbids 'arbitrary or unlawful 
interference with his or her privacy, family, home or correspondence'. Moreover, Art 23.3 provides further that 'With a view to realizing these rights, and to prevent concealment, abandonment, neglect and segregation of children with disabilities, States Parties shall undertake to provide early and comprehensive information, services and support to children with disabilities and their families'. Again, there is no comparable obligation to be found in the CRC.

As can be seen, at least some of these rights entail positive obligations being placed on state parties, and even if the scope of these obligations is (albeit to an uncertain extent) limited by Art 4.2 in respect of economic, social and cultural rights, these are positive developments for children with disabilities. For example, the right of children with disabilities, not to be excluded from the general education system and from free primary and secondary education on the basis of disability in Art 24.2(a) should trigger reinterpretation of the way in which 'special care' and 'special needs' in Art 23.2 and 23.3 CRC have often been interpreted, which is that children with disabilities should be educated outside of mainstream or general education. This is buttressed by the requirements, in Art 30.5(d) CRPD, that children with disabilities are afforded

equal access to play, recreation and sporting facilities 'including those activities in the school system', and in Art 8.2(b), to foster an attitude of respect for children with disabilities 'at all levels of the education system, including in all children from an early age'. Finally, in terms of new rights, the obligation placed on states by Art 25(b) to provide bespoke health services, including preventative services, for children with disabilities is a potentially very valuable addition to the rights of children with disabilities, and compares favourably with the requirement of Art 23.3 CRC, which provides only that children with disabilities be afforded 'effective access' to health and other services. In summary, the CRPD can be seen as providing disability rights advocates, and those advocating the rights of children with disabilities, with a truly dynamic set of rhetorical and political tools, to encourage change which is as much a matter of adopting new ways of thinking about children with disabilities as it is to do with the dedication of additional resources.

\section{New rights for all?}

Don Mackay, the Chair of the Ad Hoc Committee on a Comprehensive and Integral Convention to Promote and Protect the Rights and Dignity of Persons with Disabilities, did not actually say that the CRPD was not intended to create new rights. Rather, he said that the CRPD does not 
'for the most part' ${ }^{24}$ create new rights, which is not the same thing at all, and the CRPD does indeed contain some rights which may have the potential to benefit all children. A key example is Art 17, which provides that 'Every person with disabilities has a right to respect for his or her physical and mental integrity on an equal basis with others'. There is no equivalent standalone right to respect for integrity in any other UN human rights convention. This article reflects, albeit obliquely, concern for the particular vulnerability of persons with intellectual disabilities or mental health difficulties to compulsory medical treatment and detention, but in its final form is of more general, and unspecified, scope and application.

It is an open question whether the presence of Art 17 in the CRPD indicates that earlier conventions, including the CRC, should be modified in some way so as to also include this right. The right to physical and mental integrity is inherent in many of the CRC's articles, such as the Art 19 right to freedom from all forms of physical or mental violence, injury or abuse, neglect or negligent treatment, maltreatment or exploitation, including sexual abuse; or the Art 39 right to physical and psychological recovery and social reintegration of a child victim of any form of neglect, exploitation, or abuse, torture or any other form of cruel, inhuman or degrading treatment or punishment, or armed conflicts. But these articles have so far proven blind to such problematic issues as, for example, the circumcision of boy children, ${ }^{25}$ whereas a right to physical and mental integrity might have more purchase in this regard.

Additionally, Arts 3(f) and 9 place an obligation on state parties to ensure access to the physical and virtual environment and to transportation for disabled persons, and to develop and promulgate minimum standards and guidelines for access to all spaces open to the public, including private spaces. Space precludes fuller discussion here, but there may be scope to adapt Art 9 to the situation of children/the CRC. Indeed, it may be that compliance with Art 9 as it stands will be of benefit to all persons, including children, not just those with disabilities, if it entails the improvement of the local environment or the provision of facilities such as play areas, for example.

\section{Extending and reconfiguring existing rights}

\footnotetext{
${ }^{24} \mathrm{UN}(\mathrm{n} 3)$.

${ }^{25}$ There is a huge literature on this topic. Examples include: J. S. Svoboda 'Circumcision of male infants as a human rights violation' (2013) 39 Journal of Medical Ethics 469; J. Mazor 'The child's interests and the case for the permissibility of male infant circumcision' (2013) 39 Journal of Medical Ethics 421; P.W. Adler 'Is Circumcision Legal?' (2013) XVI(iii) Richmond Journal of Law and the Public Interest 439.
} 
The significance of the CRPD lies as much in how existing rights are presented and refashioned as it does in providing new rights. For example, although the right to life in Art 10 CRPD merely 'reaffirms' that right and seeks to ensure its effective enjoyment by persons with disabilities on an equal basis with others, Art 11 extends that protection explicitly to 'situations of risk, including situations of armed conflict, humanitarian emergencies and the occurrence of natural disasters'. One might question whether this extension will make much practical difference in such situations, but it is welcome if for no other reason than it strengthens the hand of children's rights advocates, and this is at least one idea that could usefully be borrowed by the CRC. Indeed, it seems odd that the right to life of a disabled child is better protected in this sense than the right to life of other children. This is not the only example of existing rights being extended in novel ways: another is the elevation of the right to participate effectively in society to a general principle (Arts 3(c) and 29), which goes beyond the narrow scope of Art $12 \mathrm{CRC}$, and which could usefully be followed in other areas including ICL. ${ }^{26}$

With regards to reconfiguring, the CRPD gives old rights a new twist. At several points, the convention blurs the distinction between civil/political rights and economic, social and cultural rights. For instance, the right to liberty of movement, in Art 18, is followed, in Art 19, by the right to live independently in the community, involving the positive obligation of state parties to provide a range of permanent residential accommodation (for those who desire it) and provide those services to persons with disabilities in their own homes and at locations within communities which are necessary to facilitate 'full enjoyment' of that right. Art 20 similarly requires state parties to facilitate the personal mobility of persons with disabilities 'and at an affordable cost'. It is clear from the way that these articles unfold that the view embedded in the convention is that civil and political rights depend for their realisation on the parallel realisation of economic, social or cultural rights. ${ }^{27}$

Elsewhere, political/civil rights are conflated with economic, social and cultural rights within the same article, which is an even more radical restructuring of the relationship between them. For example, the right of equality before the law is interweaved by Art 13.1 with an obligation

\footnotetext{
${ }^{26}$ The Committee on the Rights of the Child has recognised Art 12 CRC as having the status of a general principle of the CRC (CRC Committee 'General Comment No.12 on the Right of the Child T oo Be Heard' (2009), UN Doc. CRC/C/GC/12, 1 July 2009, para. 2), but the way in which Art 12 has been interpreted to datehas often led to participation which is less than 'effective': see for example L. Lundy 'Voice is not enough: Conceptualising Article 12 of the United Nations Convention on the Rights of the Child' (2007)33(6) British Educational Research Journal 927; A. Nolan 'The Child as 'Democratic Citizen' - Challenging the "Participation Gap"” (2010) 4(Winter) Public Law, 767.

${ }^{27}$ Although I don't agree with Kayess and French that the rights in Arts 19 and 20 are, as they claim, 'despite their appearance, civil and political rights': R. Kayess and P. French 'Out of Darkness into Light? Introducing the Convention on the Rights of Persons with Disabilities' (2008) 8:1 Human Rights Law Review, 1,29.
} 
placed on state parties to provide 'procedural and age-appropriate accommodations, in order to facilitate their effective role as direct and indirect participants, including as witnesses, in all legal proceedings, including investigative and other preliminary stages', coupled with training for criminal justice personnel (Art. 13.2). It seems, as access to justice is a political right, that lack of resources is not a good reason to fail to implement Art 13.

The same pattern is found in Art 21, which opens with a fairly standard version of the right to freedom of expression and opinion and requires state parties to ensure equal exercise of that right to persons with disabilities, then goes considerably further, imposing positive obligations on state parties to provide information intended for the general public in a form suitable for persons with disabilities at no cost (Art 21(a)), to facilitating the use of sign language, Braille and 'all other accessible means, modes and formats of communication' at the choice of the person with disabilities (Art 21(b)), as well as 'urging' private entities and the mass media to do the same (Arts 21(c) and (d)). This has been described by Kayess and French as 'intriguing'. ${ }^{28}$ This is because in their view Art 21 seemingly implements a civil right (freedom of expression and opinion): and yet, on a natural reading, it seems that the economic, social and cultural aspects of Art 21 are subsumed by its overarching quality as a civil/political right.

This reading is supported by the structure of Art 21, which renders the civil/political right, in Art 21.1, as the main focus of the article, with the positive obligations then placed on state parties to realise that right as Arts 21.1.a, 1.b and 1.c, which suggest that they are subcomponents of that right; there is no Art 21.2. If this analysis is correct, then the CRPD demonstrates how it is possible, in effect, to convert an aspiration into a positive obligation to be realised immediately. This might be a lesson of value to children's rights strategists although it seems to require change at the level of the wording of the text of the CRC to import this into children's rights. If the CRPD proves to set some sort of blueprint for the future articulation of rights - this novel conflation of the civil and the political with the economic, social and cultural - then the CRC will appear increasingly out of date.

It remains to be seen, however, whether the reading offered by Kayess and French will be shared by state parties and the CRPD Committee. It might be a neat textual conjuring trick to convert the aspirational into the enforceable in the way done by Art 21 and other articles within

\footnotetext{
${ }^{28}$ Kayess and French (n 26), 29.
} 
the CRPD, but that does not sit comfortably with the retention of the orthodox division between the two types of rights which is expressly made by Art 4.2 (although as suggested at 1.1.2 above, the scope of Art 4.2 is open to debate). Moreover, changing texts does not in and of itself change realities. The financial limitations on states will continue to constrain the extent to which the subcomponents of Art 21 can be realised. If Art 21 was expressly designed to challenge orthodoxies of international law obligations which entail significant financial implications, then it is a risky strategy. On the one hand, it risks the right to freedom of expression itself being seen as subject to progressive realisation, on the other it risks undermining good will towards and compliance with the convention if developing states are required to invest resources beyond their means in order to secure the immediate realisation of all elements of Art $21 .^{29}$ And even then, such immediate realisation simply will not be possible for all, perhaps many, state parties.

But at a deep philosophical and jurisprudential level something fundamental has irrevocably shifted here, as Mégret suggests. The blurring of political/civil rights with economic, social and cultural rights undermines the liberal legal subject, seen in political and civil rights terms as being independent, isolated and autonomous. This is because, in constructing civil and political rights as being interwoven with economic, social and cultural rights, the CRPD understands the legal subject as being interdependent and relational: ${ }^{30}$ we all need effective economic, social and cultural rights if we are truly to be able to exercise our civil or political rights. In this sense, the CRPD may be the vanguard of very fundamental change, the scope and impact of which we cannot really yet determine.

\section{Revisiting capacity: status, functionality, best interests and supported decision- making}

The single most radical element of the CRPD is that it marks an attempt, which cannot yet be judged to have been successful or unsuccessful, to shift the paradigm with respect to the role that the concept of 'capacity', and third-party decision-making in the 'best interests' of persons found to 'lack' capacity, has in disability law and practice. The CRPD states boldly, in Art 12, which is headed 'equality before the law', that:

\footnotetext{
${ }^{29}$ As Bartlett (n 16, 757) notes, discussing the point 'Neither choice seems particularly appealing'.

${ }^{30}$ For discussion of these concepts, see for example Martha A. Fineman 'Equality, Autonomy and the Vulnerable Subject in Law and Politics' in Martha A. Fineman and A. Grear (eds) Vulnerability: Reflections on a New Ethical Foundation for Law and Politics (2013; Ashgate: Farnham Surrey).
} 
1. States Parties reaffirm that persons with disabilities have the right to recognition everywhere as persons before the law.

2. States Parties shall recognize that persons with disabilities enjoy legal capacity on an equal basis with others in all aspects of life.

3. States Parties shall take appropriate measures to provide access by persons with disabilities to the support they may require in exercising their legal capacity.

For some, perhaps most, of those involved in the drafting of the CRPD this article was intended to prohibit national law from utilising 'capacity' as a mechanism to regulate both whether a person with disabilities is accorded legal rights and whether he or she is permitted independently to exercise those rights. This was based, first, on the conviction that even what is generally seen as the most morally defensible model of capacity - a 'functional' model which asks if the person in question can understand, retain and process information relevant to a decision, and communicate that decision to relevant others ${ }^{31}$ - has proven inadequate at prohibiting the values and preferences of third parties from percolating into the assessment of capacity, such that in truth often a covert 'status-based' test ${ }^{32}$ is deployed. In addition, the consequences of a finding of incapacity - most often a form of substituted judgement by a third party, ostensibly designed to make decisions in the best interests of the person found to lack capacity - was seen as licensing decision-making that alienated the person lacking capacity from their own life choices, and by implication often led to best interests judgements that did not in fact meet or even focus on the needs of the person with disability.

Article 12.3 demonstrates the clear preference of the drafters of the CRPD for an alternative approach - supported decision-making - in preference to substituted judgment. The key difference is that supported decision-making is posited on the assumption that capacity to make

\footnotetext{
31 This model of capacity is seen as morally defensible because it does not judge the out come of decision -making, leaving those with reduced but sufficient capacity to make their own decisions, even when from an objective point of view, the decision in question is un wise. Instead, this test asks only if the functional ability to process the relevant information is present. The English Mental Capacity Act 2005 is a fairly ty pical national law example of such an approach, and fairly typically the 2005 Act is headed by general principles of minimum interventionism: an assumption that capacity is present, with the onus on those disputing that to displace that assumption; an obligation to take 'all practicable steps' to help a person achieve capacity; as well as an embargo on judging capacity by reference to the subst ance of the decision made.

${ }^{32}$ By contrast to a functional test, a status-based test simply assumes that membership of a class of persons - such as persons with learning disabilities, or children - necessarily entails lack of capacity. In the field of mental disability, status-based tests are these days almost universally condemned as discriminatory and unfit for purpose.
} 
one's own decisions is always (or virtually always) in fact attainable, if the person of limited capacity is given the necessary assistance. For those in favour of supported decision-making, an approach which determines the extent to which a person has or may act on their rights by reference to a test of capacity breaches the prohibition on discrimination which is recognised as both a fundamental principle ${ }^{33}$ and a general obligation of state parties; ${ }^{34}$ and, to underline its importance, is also accorded its own article ${ }^{35}$ in the CRPD.

If this is correct, then it might be seen as unfortunate that the approach taken in the CRPD was to separate children with disabilities from adults with disabilities, and render children subject to the substituted judgement/best interests approach which dominates the CRC. If the CRPD had not made such provision, then children with disabilities would have had the same entitlement as adults with disabilities, to a supported decision-making rather than a substituted judgement approach. This would have in turn raised questions as to why children with disabilities had a greater entitlement to autonomous decision-making than other children, and exerted pressure to consider fundamental reform of the text of the CRC along the same lines. To me, it seems that one challenge - in terms of research needed - is to be able to articula te mechanisms which would bring supported decision-making for children into reality as the norm. This might involve, for example, the use of advocates or other support workers who take instruction from or act together with one or more children (depending on the situation), and of course training of professionals in a wide range of fields to provide such persons with the skills necessary to provide children with such support. No doubt other mechanisms could and should also be deployed. ${ }^{36}$

Beyond this, there is a yet greater potential significance to the adoption of a supported decisionmaking framework, which is deftly identified by Amita Dhanda:

'By setting up the paradigm of supported decision making, the CRPD unequivocally declares that it is possible to obtain support without being lessened or diminished. This paradigm of interdependence should be empowering and emancipatory for all of humanity and not just persons with disabilities'. ${ }^{37}$

${ }^{36}$ See, mutatis mut andis, P. Weller, 'The Convention on the Rights of Persons with Disabilities and the socialmodel of health: new perspectives' (2011) Journal of Mental Health Law 74, 77.

${ }^{7}$ Dhanda (n 9), 50.
} 
All this may be jumping the gun. As I have said, it remains to be seen whether this understanding of Art 12 becomes established internationally. ${ }^{38}$ Article 12.4 is in tension with Arts 12.1-3. Art 12.4 provides:

4. States Parties shall ensure that all measures that relate to the exercise of legal capacity provide for appropriate and effective safeguards to prevent abuse in accordance with international human rights law. Such safeguards shall ensure that measures relating to the exercise of legal capacity respect the rights, will and preferences of the person, are free of conflict of interest and undue influence, are proportional and tailored to the person's circumstances, apply for the shortest time possible and are subject to regular review by a competent, independent and impartial authority or judicial body. The safeguards shall be proportional to the degree to which such measures affect the person's rights and interests.

This provides for the possibility that a person will not in fact, even if Art 12.3 has been complied with to the fullest extent possible, have the capacity to make the decision in question. It therefore goes against the grain of the philosophy of the earlier elements of Art 12. And the drafting of Art 12 was a see-saw affair between the two camps, of substituted judgement and supported decision-making respectively. ${ }^{39}$ So it may be that the abandonment of capacity in this context is not yet upon us. ${ }^{40}$

Nonetheless, it seems odd that the CRPD, which is so clearly intended to remove discrimination on any grounds against persons with disabilities, including discrimination based on that person's age ${ }^{41}$ nonetheless supports and enhances, but does not challenge, the age-based discrimination which is inherent in the very idea that, by reason of age alone, children should be afforded less and lesser legal rights than adults, to be compensated merely with an obligat ion

\footnotetext{
${ }^{38}$ Some state parties entered reservations in respect of Art 12 for fear that it would render their own substituted judgment mec hanisms for dealing with persons found to lack mental capacity unlawful, and others signed up to Art 12 but made an interpretative declaration upon ratification, to the effect that Art 12 would be interpreted in such a way as to permit substituted decision-making. On the other hand, the Committee on the Rights of Persons with Disabilities, in its recent Concluding Observations on the initial report of New Zealand $\mathrm{CRPD} / \mathrm{C} / \mathrm{NZL} / \mathrm{CO} / 1,31$ October 2014, para.22, advised the state, which utilises substituted judgement, that it must 'take immediate steps to revise the relevant laws and replace substituted decision-making with supported decision-making'. See also Committee on the Rights of Persons with Disabilities, General Comment no. 1 Article 12: equal recognition before the law, CRPD/C/GC/1, 19 May 2014, para. 3 , wherein the Committee notes that there has been 'general failure to understand that the human rights-based model of disability implies a shift from the substitute decision-making paradigm to one that is based on supported decision-making'.

${ }^{39}$ Amita Dhanda, 'Legal capacity in the disability rights convention: Stranglehold of the past or lodestar for the future?' (2006-2007) 34

Syracuse Journal of International Law and Com 429.

40 See Fennell and Khaliq (n 16) and Bartlett (n 16).

${ }^{41}$ See Preamble, para (P), Art 8.1(b);
} 
placed on an adult decision-maker to give due weight to their views when making a substituted best interests judgment on their behalf. In other words, the paradigm-shifting question is why do the same arguments against status-based and functionality-based models of capacity which apply to adults with disabilities not also apply to the application of those models to people below the age of 18 years? The answer seems to be that those arguments are blocked and stymied by an essentialist understanding of children as a legal-political class which permeates and indeed animates the CRC: childhood in other words, as a matter of law, is constituted as a status-based limitation which is seen to affect, and delimit the capacity of, all children, regardless of actual ability. In the CRC, the essence of childhood is constructed in terms of a lack of capacity.

It does seem innocuous that -whereas for adults the key issue of the moment is whether there will be a wholesale abandonment of capacity as a mechanism to determine who can make decisions for themselves and its replacement by a supported-decision-making model, with virtually no support left amongst the international community for a status-based approach - for children the shift from status to functionality has barely begun. Possible switch points - and as an English lawyer my point of reference is the decision in the case of Gillick $v$ West Norfolk and Wisbech AHA [1986] AC 112, in which it was held that a child, on being able to demonstrate sufficient competence to pass a functional capacity test, should be entitled in law to make his or her own decisions - have been neutralised subsequently by being made subject to overriding best interests principles grounded in the status of that person as a child. ${ }^{42}$

At the very least, it can be suggested that the coming into being of the CRPD raises the questions of whether (i) it is not now time to shift from a status-based to a functionality-based understanding of the limitations that simply being a 'child' as a matter of legal status places on a young person in terms of their abilities to make decisions for themselves, and; (ii) there should be, if not an abandonment of the best interests principle, then at least the severance of that principle from a substituted judgement framework for those children found to have functional capacity and its attachment instead to a supported decision-making model. The main differe nce is that the former is 'objective' (decision made by an adult) whereas the latter is 'subjective' (decision made by the child) in orientation. In short, a child with capacity would have the legal right to decide his or her own best interests. The more radical question, of whether (iii) it is

\footnotetext{
${ }^{42}$ This situation has been theorised, for example, by Eekelaar's concept of 'aut onomy interest', which subsumes aut onomy, and rights, within a 'best interests' framework. See J. Eekelaar 'The emergence of children's rights' (1986) 6 Oxford Journal of Legal Studies 161.
} 
possible to shift the default position from childhood denoting presumptive lack of capacity, to childhood not being of itself sufficient to displace the presumption of capacity which applies to adults, is also raised (and with it a host of related questions such as whether the balance between protection and autonomy is currently appropriately figured). To put this differently, if there is widespread consensus that human rights are best protected by a 'social' model of disability, which locates the essence of the problem in the way in which society at large fails to make adequate accommodation for people with impairments, rendering such persons at risk of discrimination, how do we explain the lack of any comparable 'social model of childhood' which similarly views childhood as a time of vulnerability by reason of the same 'attitudinal and environmental barriers that hinder their full and effective participation in society on an equal basis with others'? What would the CRC and ICL in general look like if a 'social model of childhood' were to be adopted, whereby different treatment is prima facie discrimination and disempowerment? And if this is not the right question to ask, why not? And what is the right question?

\section{Concluding Comments}

In this chapter I have considered the implications of the arrival of the CRPD for ICL and the CRC in particular. I have suggested that not only does the CRPD contain important new rights and entitlements for children with disabilities, but that some of its provisions have the potential to improve the situation for children more generally, and, taken in its totality, the 2006 convention does justify the paradigm-shifting claims that have been made for it. At the least, the CRPD demonstrates how various rights in the CRC could be made more robust, and it points the way to greater involvement of individuals, communities and other actors such as NGOs in the formulation of law and policy. Beyond this, the way the CRPD restructures orthodox understandings of rights and their limits, rejects tests of capacity as disempowering and discriminatory, and does on the philosophical basis of a 'social model' of disability, raise far-reaching and awkward questions regarding the continued viability of an essentialist, statusbased, non-socialised, construction of children and their rights. 